\title{
European top managers' support for work-life arrangements
}

\author{
Wike M. Been ${ }^{\text {a, * }}$, Tanja van der Lippe ${ }^{c}$, Laura den Dulk ${ }^{b}$, Maria Das Dores \\ Horta Guerreiro ${ }^{\mathrm{d}}$, Aleksandra Kanjuo Mrčela ${ }^{\mathrm{e}}$, Charlotta Niemistöo ${ }^{\mathrm{f}}$ \\ ${ }^{\text {a }}$ University of Amsterdam, The Netherlands \\ b Erasmus University Rotterdam, The Netherlands \\ ${ }^{\mathrm{c}}$ Utrecht University, The Netherlands \\ ${ }^{\mathrm{d}}$ University Institute of Lisbon, Portugal \\ e University of Ljubljana, Slovenia \\ ${ }^{\mathrm{f}}$ Hanken University, Finland
}

\section{A R T I C L E I N F O}

\section{Article history:}

Received 22 March 2016

Received in revised form 19 December 2016

Accepted 17 February 2017

Available online 24 February 2017

Top managers-defined as CEOs, CFOs and members of boards of directors-decide to what degree their organization offers employees work-life arrangements. This study focuses on the conditions under which they support such arrangements. A factorial survey of 202 top managers in five European countries was conducted in 2012. The analyses are based on 1212 vignettes. Implications are drawn from an integrated framework of neo-institutional theory, business case argumentation and the managerial interpretation approach. The results show that top managers simultaneously consider multiple conditions in deciding upon their support for work-life arrangements (i.e., the costs involved, the return in terms of employee commitment, and the type of arrangement, specifically having a preference for flextime and telecommuting over leave policies and part time hours). Additionally, they favor work-life arrangements designed for all employees above work-life arrangements granted to specific employees. How top managers weigh certain conditions depends on the organizational and national contexts. Their personal characteristics, however, do not seem to explain their support for work-life arrangements.

\section{Introduction}

Marissa Mayer of Yahoo! reduced the flexible working options of employees after taking over for her predecessor, and Mark Zuckerberg of Facebook extended parental leave options after becoming a father himself. These examples suggest that CEOs, CFOs and members of boards of directors-hereafter referred to as "top managers"-are of vital importance to work-life arrangements offered by organizations (Bardoel, 2003; Kossek et al., 1994; Milliken et al., 1998). These work-life arrangements can be defined as organizational policies that help employees combine work and private responsibilities. Options include paid parental leave, paid leave to take care of sick family members, flextime, reduced hours and telecommuting (Ollier-Malaterre et al., 2013).

The literature about the provision of work-life arrangements by organizations acknowledges that it is ultimately top managers who decide on the organizations' strategy regarding the adoption of work-life arrangements (Bardoel, 2003;

\footnotetext{
* Corresponding author. Hermelijnvlinderdijk 197, 3544 ZD Utrecht, The Netherlands.

E-mail address: w.m.been@uva.nl (W.M. Been).
} 
Milliken et al., 1998; Kossek et al., 1994; Osterman, 1995). Nonetheless, studies aiming to explain the provision of work-life arrangements by organizations have insofar only indirectly taken top managers into account. Some studied the relevance of their attitudes through reports from HR managers, showing that organizations with a top manager who has a positive attitude toward work-life arrangements tend to provide more of these arrangements (Bardoel, 2003; Kossek et al., 1994; Ollier-Malaterre, 2009). However, many studies treat the decision to provide work-life arrangements as if organizations themselves somehow make these decisions (Den Dulk and Groeneveld, 2012).

To account for the fact that the provision of work-life arrangements is the outcome of the active and strategic decisionmaking of top managers, we take a first step to include top managers explicitly in the literature regarding work-life arrangements by conducting a vignette study among them. To our knowledge, this is the first vignette study among this hardto-reach group of respondents in the body of literature regarding the provision of work-life arrangements by organizations. Taking them as the subject of study regarding the provision of work-life arrangements has some important advantages. First, it gives the option of observing their decision-making directly, enabling the study of which considerations are ultimately important for decisions regarding the provision of work-life arrangements within organizations. This helps answer questions such as whether it is ultimately business-focused arguments, such as costs, that are decisive for the provision of work-life arrangements or whether institutional pressures primarily drive their provision. This is a central question that has recently been voiced by a group of researchers in the field (Ollier-Malaterre et al., 2013). Second, studying top managers allows us observe how personal characteristics of top managers matter for their support for work-life arrangements. For example, are female top managers more likely to support them than their male counterparts? Do their personal experiences with work-life arrangements matter? The relation between personal characteristics and experiences of decision-makers and their decisions regarding organizational work-life arrangements has been suggested in the literature but is untested (Hambrick and Mason, 1984; Hopkins, 2005; Klein et al., 2000).

Top managers are situated simultaneously in organizational and national contexts. Previous research has revealed systematic differences between various types of organizations and the work-life arrangements they provide. For example, public-sector and larger organizations tend to offer a broader spectrum of arrangements (e.g., Davis and Kalleberg, 2006; Den Dulk et al., 2010; Goodstein, 1994; Wood et al., 2003). There are also national differences in organizations' work-life arrangements offered in addition to statutorily required policies (e.g., Den Dulk et al., 2010; Den Dulk et al., 2012; Den Dulk et al., 2013; Lewis, 2003; Lewis and Haas, 2005; Lyness and Kropf, 2005; Ollier-Malaterre et al., 2013). This implies that top managers make different decisions about the provision of work-life arrangements in different contexts. The support of top managers for work-life arrangements, therefore, needs to be studied in relation to the organizational and national context, as decisions seem to vary accordingly. Hence, the research question of the present study is: When do top managers support the provision of work-life arrangements in their organization, and how do the conditions that are decisive for their support vary between organizational and national contexts?

To study top managers' support for work-life arrangements and to relate this to organizational and national contexts, unique data were collected among top managers from a range of organizations in five different European countries: Finland, the Netherlands, the United Kingdom, Slovenia and Portugal. These countries were selected from different areas of Europe to ensure variety in national context, as work-life arrangements provided by organizations have been shown to vary accordingly (Den Dulk, 2001). Selection was broadly based on division into welfare state regimes (Esping-Andersen, 1999). Variety in welfare state regime means variety in state policies and gender equality, which are shown to be important for the provision of work-life arrangements (Den Dulk et al., 2010; Lyness and Kropf, 2005). A total of 202 top managers in these five countries participated in the survey. A vignette design (also called a factorial survey) was used to capture the conditions under which top managers within these countries support work-life arrangements. In a vignette study, the respondents are asked to respond to descriptions of hypothetical situations, called vignettes (Atzmüller and Steiner, 2010; Rossi and Anderson, 1982; Wallander, 2009). This approach is suitable for understanding variation in interpretation and decision-making, as it gives a common point of reference to all respondents. Moreover, it allows a simultaneous analysis of factors that affect a decision. The advantage of a factorial survey design over a traditional survey design is, therefore, that the former allows for disentangling the conditions that affect decisions that are normally difficult to distinguish (Wallander, 2009). Hence, it allows looking at the conditions ultimately decisive for top managers' decisions to support work-life arrangements. An additional advantage is that confronting top managers with several such factors in a vignette is more realistic than a traditional survey, as decision situations are also complex in real life (Atzmüller and Steiner, 2010). This approach has already been successful in examining the allowance decisions of supervisors and attorneys to allow work-life arrangements (Den Dulk and De Ruijter, 2008; Klein et al., 2000; Powell and Mainiero, 1999). However, to our knowledge this is the first study in which a factorial survey is applied to understanding the adoption of work-life arrangements in the organization's policies in the first place.

\subsection{Theory}

In the literature about the provision of work-life arrangements, the following theoretical approaches have been applied to explaining their adoption by organizations: neo-institutional theory, business case argumentation and the managerial interpretation approach. They have been used separately or combined in an integrated approach in different combinations, and they all contain assumptions about decision-makers. However, as top managers have not been studied directly in this body of literature, these assumptions have not been tested at the level of the decision-maker but rather at the level of the organization. In this study, we first combine all three theoretical approaches to give an overview of how the literature has 
addressed them insofar. Next, we form hypotheses about what these theoretical approaches would mean for top managers' decision-making about whether to provide work-life arrangements to address assumptions at the decision-makers level.

\subsection{How the different theories fit together: an integrated framework}

Most studies toward the adoption of work-life arrangements by organizations incorporate neo-institutional theory. This theory is based on the idea that organizations follow social rules and conventions, called institutional pressures (Ingram and Simons, 1995). There are various sources in society that push organizations to follow these, such as laws and regulations (coercive pressure), expectations of employees and professional groups within the organization (normative pressure), and other organizations (mimetic pressure) (DiMaggio and Powell, 1983). This means that top managers will support work-life arrangements when doing so is reinforced, in line with what is expected of them or in line with what others are doing. Neo-institutional theory incorporates the idea that active and strategic choices are made by managers, who choose how to respond to institutional pressures (Goodstein, 1994; Ingram and Simons, 1995; Oliver, 1991; Osterman, 1995). To understand further the strategy that is determined by managers, some researchers incorporated business case argumentation (Den Dulk, 2001; Den Dulk et al., 2010; Dex and Scheibl, 2001; Osterman, 1995). Applying business case argumentation means that top managers will strategically choose to support work-life arrangements when they feel the benefits outweigh the costs and thus contribute to achieving the organization's goals or at the very least are not counterproductive. From a business case perspective, the main organizational goal would be profitability (Glass and Fujimoto, 1995). However, other organizational goals are also likely to be important to top managers: a good public reputation, social legitimacy and a good relationship with employees (Den Dulk, 2001). Hence, top managers are likely to evaluate work-life arrangements against a variety of goals. To account for the subjective decision-making of managers, other researchers have incorporated the managerial interpretation approach into neo-institutional theory (e.g., Bardoel, 2003; Goodstein, 1994; Kossek et al., 1994; Milliken et al., 1998; Morgan and Milliken, 1992). According to this approach, managers must first signal the need for work-life arrangements, after which they have to make an active decision to push for their adoption (Milliken et al., 1998). Applied to top managers, this theory implies that the personal awareness of top managers about employees' need for these arrangements is crucial for their adoption. In the following sections, we will use the different theoretical approaches to deduce hypotheses.

\subsection{Business case argumentation}

The basic behavioral assumption within business case argumentation is that top managers weigh the costs and benefits of work-life arrangements when deciding upon their support for these arrangements. Therefore, the costs and benefits associated with work-life arrangements can be expected to play a central role in top managers' considerations. There are different types of costs associated with work-life arrangements. A first type is their potential for disrupting employee output (Den Dulk and De Ruijter, 2008). Work-life arrangements can potentially lower employee output when they remove employees from the workforce, either wholly (i.e., through leave arrangements) or in part (i.e., through part-time working hours). When employees take a longer period of leave, top managers need to hire replacements or rearrange the work (Powell and Mainiero, 1999). The potential for disrupting employee output varies between different types of work-life arrangements. Therefore, top managers might be expected to evaluate work-life arrangements separately. Business case argumentation would expect top managers to be more supportive of work-life arrangements that allow employees to continue working full time because this does not jeopardize employees' output. This is predominantly the case with flextime and telecommuting, which change employee schedules and work locations but not their output. Telecommuting allows employees to work from different locations but does not change the hours that employees work. This is different for work-life arrangements such as part-time working hours and leave arrangements, as these arrangements result in employees' working fewer or no hours (for a certain period of time). From this, the first hypothesis follows: 1) Top managers are more supportive of flextime and telecommuting than leave arrangements and part-time working hours.

Another type of cost associated with work-life arrangements is financial investments, which might be caused by the need to retrain supervisors about how to supervise employees when flexible work hours or telecommuting are introduced because they can no longer evaluate employees based on their presence, which costs money (Den Dulk and De Ruijter, 2008; Powell and Mainiero, 1999). Additionally, the work-life arrangements themselves might require a financial investment such as, for example, if the organization supplements statutory unpaid parental leave with additional pay during the leave period. When top managers base their support for work-life arrangements on a cost-benefit analysis, it implies that the financial costs involved are a central consideration and that they are likely to support work-life arrangements when the financial costs involved are low. In order to test whether this basic assumption accounts for top managers' decisions whether to provide work-life arrangements, we hypothesize that, 2) The fewer financial costs associated with work-life arrangements, the more likely top managers are to support them.

There are also various organizational benefits associated with work-life arrangements; for example, enhanced employee commitment is central in the literature (Haar and Spell, 2004; Konrad and Mangel, 2000; Lambert, 2000; Muse et al., 2008). Top managers might regard this as beneficial for the organization because the prosperity of many organizations depends on its employees. Committed employees will remain in the organization and work hard. Enhanced employee commitment is linked to work-life arrangements through the principle of reciprocity: when employees feel that they are getting something from the organization (e.g., work-life arrangements), they are willing to do something in return (Lambert, 2000; Osterman, 
1995). When top managers evaluate work-life arrangements against the costs and benefits, a potential enhancement of employee commitment is likely to be a central consideration. In line with this, we hypothesize that, 3) It is more likely that top managers will support work-life arrangements when they are expected to increase employee commitment.

Another benefit of work-life arrangements commonly mentioned in the literature is that they contribute to attracting and retaining talented employees (Barney, 1991; Davis and Kalleberg, 2006; Den Dulk, 2001; Jones et al., 2013; Mescher et al., 2010; Osterman, 1995; Poelmans et al., 2003; Turban and Greening, 1996; Wood et al., 2003). A quality-motivated and high-talent workforce can be a source of competitive advantage for an organization (e.g., Barney, 1991). Top managers might be able to make their organization more competitive by offering specific employees who are exceptionally good at what they do custom work-life arrangements as a personal favor (Caligiuri and Givelekian, 2008; Hornung et al., 2009). This will tie the employee to the organization purely for rational reasons: it will be very hard to obtain the same benefits at another organization (Davis and Kalleberg, 2006). Additionally, besides offering work-life arrangements only to high-performing employees because it might be more exclusive and thus more effective, it is also cheaper than offering them to all employees: fewer financial and organizational costs are involved. Hence, we expect top managers to favor work-life arrangements aimed at the best employees, leading to the hypothesis that, 4) Top managers are more likely to support work-life arrangements aimed at high-performing employees as opposed to work-life arrangements for all employees in the organization.

\subsection{Neo-institutional theory}

Central to neo-institutional theory is the reasoning that organizations in the same field put mimetic pressure on other organizations to follow them in the provision of work-life arrangements. The underlying reasoning is that organizations copy market-leaders in their field because it is hard to observe the whole environment and accordingly decide what would be the best course for their organization (Cook, 2004; DiMaggio and Powell, 1983). Therefore, they opt for what others are doing and follow the developments in their field. They do so without knowing whether this might be the most rational thing for their organization to do. If neo-institutional theory accounts best for the provision of work-life arrangements, the course of action of organizations in the same field can be expected to be central to top managers' decision making. Based on mimetic pressure top managers can be expected to support work-life arrangements in their organization when others in their field also do it, but not when they are one of the first and it would make them a forerunner. After all, under this last scenario, there would be little mimetic pressure. Therefore, it is to be expected that, 5) Top managers are more likely to support work-life arrangements when competitors also do so, as opposed to when it would make them a forerunner in their field.

Neo-institutional theory, moreover, entails that top managers will follow social norms regarding work-life arrangements. Previous studies have shown that a social norm for organizations to provide work-life arrangements might stem from a high level of national gender equality (Den Dulk and Groeneveld, 2012; Den Dulk et al., 2010; Lyness and Kropf, 2005). The underlying idea is that when the level of gender equality is high, an effort to bridge inequalities between men and women in the labor market is valued. Work-life arrangements are often associated with helping women achieve a position in the labor market; these arrangements are, therefore, valued in those countries (Korabic et al., 2003; Lyness and Kropf, 2005; Poelmans and Sahibzada, 2004). The Gender Inequality Index of 2011 (UNDP, 2011), shows that gender equality in 2011 was highest in the Netherlands (ranked 2), followed by Finland (ranked 5), Portugal (ranked 19), Slovenia (ranked 28) and the UK (ranked 34). In line with the argument that top managers will follow social norms and be more supportive when the level of gender equality is higher, it is hypothesized that, 6) Top managers in the Netherlands and Finland are more supportive of work-life arrangements than those in Portugal, Slovenia, and the UK.

\subsection{Managerial interpretation approach}

According to the managerial interpretation approach, managers need to be aware of the need for work-life arrangements before they will support their introduction. This means that the more salient issues around the combination of work and private life are to top managers, the more they will see the value of work-life arrangements. Some personal characteristics make it more likely that top managers are aware of the need for these arrangements (Hambrick and Mason, 1984; Hopkins, 2005; Klein et al., 2000). For example, work-life arrangements are often associated with women in the labor force (Den Dulk, 2001), and with having children. Therefore, female top managers and top managers with children might be more aware of the issue of work-life balance. Furthermore, top managers who have experienced work-life conflicts, personally used work-life arrangements in the past or are currently using them might be more aware of their value to employees because of their personal experiences. Accordingly, it is hypothesized that, 7) Female top managers, those with children and top managers who have personal experience with the use of work-life arrangements and/or work-life conflicts are more likely to support work-life arrangements.

\subsection{Organizational context: combining neo-institutional theory and business case argumentation}

The conditions that are ultimately decisive for top managers' support for work-life arrangements might vary between top managers of different organizations or countries. Based on an integrated framework of neo-institutional theory and business case argumentation, scholars have argued that organizational characteristics are related to the provision of work-life arrangements because different types of organizations also have different goals (Den Dulk et al., 2010). When different goals are 
important, it is likely that top managers will base their decision about whether to support work-life arrangements on other conditions of work-life arrangements. Within the literature, it is consistently found that public-sector organizations provide more work-life arrangements than private-sector organizations (Davis and Kalleberg, 2006; Den Dulk et al., 2010; Goodstein, 1994; Wood et al., 2003). The difference between these types of organizations is explained by the greater reliance on the public legitimacy of public-sector organizations and NGOs (Den Dulk, 2001). For this reason, they are more sensitive to norms within society about providing work-life arrangements (e.g., Goodstein, 1994). Therefore, it is rational for public-sector organizations and NGOs to follow institutional pressure. Thus, business case argumentation aligns with neo-institutional theory when public-sector organizations follow institutional pressure. Private-sector organizations, however, are profit-driven. Therefore, they can be expected to be more cost-oriented rather than norm-oriented and more likely to let financial costs be decisive for their support. Hence, it is expected that, 8) The negative relationship between the financial costs of work-life arrangements and the support of top managers for these arrangements is stronger for top managers at private-sector organizations than for top managers at public-sector organizations and NGOs.

However, because public legitimacy is important to public-sector organizations and NGOs (Goodstein, 1994; Ingram and Simons, 1995), their top managers are likely to be more concerned with how work-life arrangements affect the public reputation of their organizations (Den Dulk, 2001). The provision of work-life arrangements may only contribute to an organization's public reputation when it is perceived as "fair." We, therefore, argue that the provision of work-life arrangements is only likely to contribute to the public legitimacy of the organization when their work-life arrangements target all employees and not only high-performing ones. Providing work-life arrangements only to high-performing employees may be seen as unfair and thus as harmful rather than beneficial for an organization's public reputation. As a result, top managers at public-sector organizations and NGOs are more likely to support organization-wide work-life arrangements than reserve them for the best performers. Providing these arrangements only to the best performers to attract and retain them for the organization might however be more cost-effective, which is more aligned with the profit-orientation of private-sector organizations. Therefore, it is hypothesized that, 9) Top managers of public-sector organizations and NGOs have a preference for work-life arrangements for all employees over work-life arrangements only for high-performing employees, while top managers of private-sector organizations prefer work-life arrangements for high-performing employees.

\subsection{State policies: combining neo-institutional theory and the managerial interpretation approach}

Scholars have argued that national differences in the provision of work-life arrangements by organizations result from variation in the prevailing level of state policies supporting citizens in combining work and family responsibilities (Den Dulk et al., 2010; Lewis and Haas, 2005). Based on neo-institutional theory, scholars have argued that extensive state policies pressure organizations to extent these by offering work-life arrangements because extensive statutory rights enhance a normative climate in which supporting the work-life balance of employees is valued (Lewis, 2003; Lewis and Haas, 2005). Using the managerial interpretation approach, however, others have reasoned that organizations provide fewer work-life arrangements while the state provides many. They do not feel it is the organization's responsibility because the government already takes care of it (Den Dulk et al., 2010). Recently, Den Dulk et al. (2010) found that both arguments are true. In countries with high levels of state support, in line with the managerial interpretation approach, organizations provide fewer work-life arrangements in a domain similar to one for which state support is provided, such as with the example of leave policies. However, they provide more work-life arrangements in domains where the state is not involved, such as telecommuting or flextime, which aligns with neo-institutional pressure. Of the countries in this study, Finland's public expenditure on family policies tends to be relatively high, and its government provides universal services such as a range of leave arrangements based on the ideal of gender equality (Niemistö, 2011). The Slovene government also offers an extensive system of maternity and paternity leave policies and a universal day-care system (Stropnik and Šircelj, 2008), which is mainly a hold-over from before 1990. For the other three countries, the leave arrangements are less extensive although still prevalent because they must all comply with EU legislation (Saraceno, 2011). Consequently, we expect that, 10) Top managers in Finland and Slovenia will be more supportive of flextime and telecommuting and less supportive of parental leave and parental leave for fathers than top managers in the Netherlands, Portugal and the UK.

\section{Data, methodology and operationalization}

\subsection{Data}

Data collection took place in 2012 among top managers at a broad range of organizations in the Netherlands, the UK, Slovenia, Portugal and Finland. Managers were selected if they a) held a position in the highest ranks of their organizations, such as CEO, CFO or a member of the board of directors (our definition of top manager) and b) were a top manager of an organization with at least ten employees. We selected the cut-off point of ten employees because government regulations often do not apply to, or are different for, very small organizations.

Because top managers are part of the social elite, they are particularly hard to access (Aberbach and Rockman, 2002; Goldstein, 2002). We worked with experts in the countries under study to develop the best approach to accessing top managers. Different methods were used. Approximately 60 percent of respondents were reached through personal networks and contacts with organizations of business leaders. Contacts with these organizations were particularly helpful in Slovenia 
and Finland. Another 10 percent were included through snowball sampling, a method applied in all countries. In the Netherlands and the UK, social media was used to contact additional respondents, which resulted in adding nearly 5 percent of the respondents. Finally, a cold approach after selection from the internet was applied to contact similar organizations in all countries when we missed important types of organizations in a specific country or were in need of more respondents. Approximately 25 percent of the sample was reached this way. Top managers were first contacted through letter (both mail and email). Subsequently, we contacted them to discuss participation in the study. The combination of strategies gave us access to a hard-to-reach population, resulting in a sample of 202 top managers in five countries. Owing to the different methods used to find respondents, a reliable response rate cannot be calculated. Our sample is comparable to the 2009 European Company Survey (Eurofound, 2010) in terms of the proportion of private-sector organizations, but we do have an oversampling of large organizations with more than 500 employees (largest category in the European Company Survey).

\subsection{The factorial survey}

To study the conditions under which top managers support work-life arrangements, a factorial survey design was adopted (also referred to as a vignette study) featuring vignettes and background questions. A vignette is a hypothetical description of a situation in which certain factors that are considered relevant to a decision are systematically varied in the form of a short story (Rossi and Anderson, 1982). Top managers were given descriptions of hypothetical situations in which a manager in their own organization proposes to urge supervisors to permit employees to take up a certain type of work-life arrangement. We chose this rather than focusing only on formal policies in organizations-a common approach in the literature (e.g., Den Dulk et al., 2010)-because the formal adoption of work-life arrangements does not mean that employees actually benefit from them (Allen, 2001). By focusing on whether offering work-life arrangements is encouraged within organizations, we aim to understand the conditions under which top managers are willing to support the active adoption of these arrangements. The vignettes were written stories, given to the top managers in the languages of their respective countries. The vignettes were translated and back-translated (by different people) to make sure that the intended meaning was not changed in the translation process.

Vignette factors and factor levels: independent variables. The work-life arrangements covered in the hypothetical situations, known as vignette factors, are based on the concepts set out in the hypotheses. They are 'type of organizational work-life arrangement', 'costs', ‘employee commitment', ‘employee target group' and 'other organizations'. Each vignette factor has two or more variants, called factor levels, which we varied systematically between hypothetical situations. Table 1 reviews the six factors and their factor levels. For analysis purposes, we created dummies for the factor levels. They are included in the analyses as independent variables.

When the factor levels of the five different factors are varied systematically, a total vignette population of 96 different vignettes can be created (calculated by multiplying the number of factor levels for each factor: $6^{\text {type }} \times 2^{\text {costs }} \times 2^{\text {commitment }} \times$ $2^{\text {employee target group }} \times 2^{\text {other organizations }}$ ). We divided the 96 stories into 16 subsets of six vignettes and presented each top manager with a subset of six vignettes. We choose to assign each top manager a subset, because it would have been too much to ask top managers to respond to the entire population of vignettes. This approach ensured that each vignette was assessed at least eight times and at most seventeen times (Atzmüller and Steiner, 2010), with an average of 12.4 assessments per vignette. The order in which the respondent responded to the six vignettes varied randomly to avoid order effects. Below is an example of how the vignettes were formulated. The alternative factor levels are shown in brackets.

\section{Example of vignette}

One of your organization's managers suggests to stimulate supervisors to permit flextime [paid parental leave; paid parental leave for fathers; short term care leave; a four-day workweek; working from home for one day a week on a

Table 1

Vignette factors and factor levels.

\begin{tabular}{lll}
\hline Factor & Factor levels \\
\hline 1 Type of organizational work-life arrangement & 0) four-day work week (part-time hours)* \\
& 1) (fully)paid parental leave \\
& 2) (fully)paid parental leave for fathers \\
& 3) short-term care leave \\
2 Costs & 4) working from home on a structural basis for one day a week (telecommuting) \\
3 Employee commitment & 5) flextime \\
4 Employee target group & 0) the implementation of the policy requires a financial investment*
\end{tabular}

Note: * Reference category. 
structural basis] to exceptionally well performing employees [employees]. Implementation of this policy requires a financial investment [will not cost the company anything extra in the long run] and it increases employee commitment to the organization [it is unclear whether it causes an increase in employee commitment to the organization]. Stimulation of this policy makes you a precursor compared to other organizations in your field [other organizations in your field also have plans to promote this policy].

Judging the vignettes: dependent variable. The top managers were asked to indicate whether they 'would agree to this proposal (yes/no).'

Top managers and organizations: independent, moderating and control variables. After responding to the vignettes, the top managers were asked to answer some additional questions about themselves and their organizations. The sector to which the organization belongs was added to the analyses. This variable was coded as a dummy variable, with the private sector set as the reference category. Countries were added to the model as dummy variables, with the Netherlands set as the reference category. Sex was added as a dummy variable, with male as the reference category. The personal use of work-life arrangements by top managers was calculated by combining a variable about the past use of work-life arrangements by top managers (yes/no) and another variable about their current use of these arrangements (yes/no). The answer 'no' to any of these variables was used as the reference category. Moreover, whether the top manager ever experienced work-life conflict was added as a dummy to the analysis, with never having ever experienced work-life conflict as the reference category. Whether the top manager had children was included as a dummy variable, with not having children as the reference category.

Several of the characteristics of the top managers and their organizations were added to the analysis as control variables. As larger and financially healthy organizations are in a better position to provide work-life arrangements (Den Dulk et al., 2010), we controlled for size and financial situation. Because the size of the organization is not normally distributed, three size categories were created: small organizations with 10-100 employees, medium-sized organizations with 101 to 1000 employees, and large organizations with more than 1000 employees. The categories were added to the analyses as dummy variables, with small organizations as the reference category. For the financial situation of the organization, we asked the top managers to rate their organization's financial status. The answer categories were growing, stable, shrinking slightly and shrinking. The categories were added to the analyses as a continuous variable. We controlled for age of the top manager because younger managers might be more familiar with the idea of work-life arrangements. It was added as a continuous variable. Moreover, we controlled for the educational direction of the top manager, distinguishing three categories: 1) beta/ business related studies (reference category), 2) alpha/gamma studies and 3) educational levels below university. The industry was added as a control variable, distinguishing four categories: 1) private services, 2) public services, 3) production and retail and 4) knowledge work. Private services served as the reference category. We also included a continuous control variable for the number of years the top manager has been in this position because work-life arrangements are policies that might only yield benefits in the long-term, making top managers that are in their position for a longer period more likely to support them. Finally, we added a dummy variable for whether the top managers are married or are living as married, with not (living as) married as the reference category.

\subsection{Method of analysis}

One key characteristic of a factorial survey design is that the vignette, and not the respondent, is the unit of analysis. Since each top manager was asked to rate six vignettes, it could be argued that the vignettes are nested within the top managers. A common approach to analyzing vignette data is multilevel models (Atzmüller and Steiner, 2010). Because of the dichotomous dependent variable, we used a logistic multilevel regression model in which top managers were the random factor and in which the top manager's response to the vignette was the dependent variable. Countries were added as dummy variables, and we used interactions with vignette characteristics rather than using a three-level model to test differences between countries because the data contains only five countries, which is too few for adding a country level to the models.

The dataset contained 1212 vignettes nested in 202 top managers. We dealt with missing values by means of multiple imputation, with 25 imputations for each missing value. Missing values were separately imputed at both levels to take into account the multi-level structure of the data. Missing values were imputed for the following variables at the level of the top manager (second level): sex (1 missing value), married ( 2 missing values), children (1 missing value), financial situation (1 missing value), industry (4 missing values), educational direction (5 missing values), and tenure (23 missing values). Additionally, 88 missing values were imputed at the vignette level regarding the decision whether to support the vignette or not.

To test the hypotheses, three different models were developed. The first model is a random intercept model, used as a test for the first seven hypotheses. All vignette factors, the characteristics of the top managers and their organizations, the countries and the control variables were added. The second model is a random intercept, random slope model including cross-level interactions between the sector of the organization and the vignette characteristics 'costs' and 'target group of employees', as a test for hypotheses 8 and 9 . The third model is also a random intercept, random slope model including crosslevel interactions; however, this time it revealed interactions between country and the vignette characteristic 'different types of work-life arrangements'. To limit the number of random slopes, the 'different types of work-life arrangements' were combined to three groups: part-time work hours (reference category), flextime/telecommuting, and leave policies (which combines paid parental leave, paid parental leave for fathers, and short term care leave). This forms a test for hypothesis 10. 


\section{Results}

\subsection{Descriptive statistics}

Table 2 shows the descriptive statistics of the variables in the analysis. Top managers supported 66 percent of the vignettes. Most of the top managers work for private-sector organizations (71 percent) and are male (69 percent). A majority (57 percent) has ever personally used, or is currently using, work-life arrangements. Also 57 percent of the top managers ever experienced work-life conflict themselves. Over three-quarters of the respondents (77 percent) has children, and they are on average 48 years old. Although we have an oversampling of large organizations compared to the complete population of organizations, the majority of respondents belong to small organizations (40 percent). Another 26 percent work for large organizations with 1000 employees or more. Most of the top managers have a business or a beta educational background (66 percent) and are leading a private services company (32 percent). The large majority is married (92 percent). The financial situation of their organizations is stable on average (mean of 2.22 on a scale from 1 (growing) to 4 (shrinking)), and they are on average 6.5 years in their current position. The correlations between the level-two variables are not so high as to preclude being included in the models together.

Table 2

Descriptive statistics of dependent, independent and control variables.

\begin{tabular}{|c|c|c|c|c|}
\hline Factor/Variable & Factor level/Category & Range & Mean/Prop. & SD \\
\hline \multicolumn{5}{|l|}{ Dependent variable } \\
\hline Top managers' support & & $0 / 1$ & 0.66 & - \\
\hline \multicolumn{5}{|l|}{ Vignette factors (level 1) } \\
\hline \multirow[t]{6}{*}{ Type of work-life arrangement } & Paid parental leave & $0 / 1$ & 0.17 & - \\
\hline & Paid parental leave for fathers & $0 / 1$ & 0.17 & - \\
\hline & Short-term care leave & $0 / 1$ & 0.17 & - \\
\hline & Telecommuting & $0 / 1$ & 0.17 & - \\
\hline & Flextime & $0 / 1$ & 0.17 & - \\
\hline & Part-time hours & $0 / 1$ & 0.17 & - \\
\hline \multirow[t]{2}{*}{ Costs } & No investment & $0 / 1$ & 0.50 & - \\
\hline & Investment & $0 / 1$ & 0.50 & - \\
\hline \multirow[t]{2}{*}{ Commitment } & Increasing & $0 / 1$ & 0.50 & - \\
\hline & Unclear whether increasing & $0 / 1$ & 0.50 & - \\
\hline \multirow[t]{2}{*}{ Employee target group } & Employees & $0 / 1$ & 0.50 & - \\
\hline & Exceptionally well performing employees & $0 / 1$ & 0.50 & - \\
\hline \multirow[t]{2}{*}{ Other organizations } & No & $0 / 1$ & 0.50 & - \\
\hline & Yes & $0 / 1$ & 0.50 & - \\
\hline \multicolumn{5}{|l|}{ Other variables (level 2) } \\
\hline \multirow[t]{5}{*}{ Country } & Netherlands & $0 / 1$ & 0.25 & - \\
\hline & Finland & $0 / 1$ & 0.16 & - \\
\hline & Portugal & $0 / 1$ & 0.24 & - \\
\hline & Slovenia & $0 / 1$ & 0.20 & - \\
\hline & $U K$ & $0 / 1$ & 0.15 & - \\
\hline \multirow[t]{2}{*}{ Sector } & Private & $0 / 1$ & 0.71 & - \\
\hline & Other & $0 / 1$ & 0.29 & - \\
\hline \multirow[t]{2}{*}{ Sex } & Male & $0 / 1$ & 0.69 & - \\
\hline & Female & $0 / 1$ & 0.31 & - \\
\hline \multirow[t]{2}{*}{ Personal use of work-life arrangements } & No & $0 / 1$ & 0.43 & - \\
\hline & Yes & $0 / 1$ & 0.57 & - \\
\hline \multirow{2}{*}{$\begin{array}{l}\text { Personal experience work-life } \\
\text { conflict }\end{array}$} & No & $0 / 1$ & 0.43 & - \\
\hline & Yes & $0 / 1$ & 0.57 & - \\
\hline \multirow[t]{2}{*}{ Children } & No & $0 / 1$ & 0.23 & - \\
\hline & Yes & $0 / 1$ & 0.77 & - \\
\hline \multicolumn{5}{|l|}{ Control variables } \\
\hline Age & In years & $27-67$ & 48.15 & 9.13 \\
\hline \multirow[t]{3}{*}{ Size } & Small & $0 / 1$ & 0.40 & - \\
\hline & Medium & $0 / 1$ & 0.34 & - \\
\hline & Large & $0 / 1$ & 0.26 & - \\
\hline \multirow[t]{3}{*}{ Educational direction } & Business \& beta & $0 / 1$ & 0.66 & - \\
\hline & Alpha \& gamma & $0 / 1$ & 0.25 & - \\
\hline & Below university level & $0 / 1$ & 0.09 & - \\
\hline \multirow[t]{4}{*}{ Industry } & Private services & $0 / 1$ & 0.32 & - \\
\hline & Public services & $0 / 1$ & 0.18 & - \\
\hline & Production \& retail & $0 / 1$ & 0.24 & - \\
\hline & Knowledge work & $0 / 1$ & 0.26 & - \\
\hline \multirow[t]{2}{*}{ Married } & No & $0 / 1$ & 0.08 & - \\
\hline & Yes & $0 / 1$ & 0.92 & - \\
\hline Financial situation of the organization & Growing - shrinking & $1-4$ & 2.22 & 0.93 \\
\hline Tenure & Years in position & $0.1-30$ & 6.46 & 5.92 \\
\hline
\end{tabular}




\subsection{Models}

Table 3 shows the results of the multilevel logistic regression models with which the hypotheses are tested. The table reports odds ratios and standard errors between brackets. Based on an empty model (not shown), the intraclass correlation coefficient (ICC) has been calculated, which is 0.25 , showing that 25 percent of the variance can be attributed to the top manager/organization/country level and 75 percent to the vignette level. Model 1 shows the result of the multilevel random intercept model. All but one of the basic hypotheses drawn from business case argumentation are supported by the model. The model indicates that in general, top managers are least favorable toward part-time work, as all other types (with the exception of parental leave) of work-life arrangements are valued more positively by the top managers. Top managers are most positive about flextime, as they are $6.28(\mathrm{p}<0.01)$ times more likely to support flextime than part-time work Moreover, they are also more favorable toward telecommuting (odds ratio of 3.57, $p<0.01$ ), parental leave for fathers (odds ratio of 2.46, $\mathrm{p}<0.01$ ), short-term care leave (odds ratio of 3.43, $\mathrm{p}<0.01$ ) and parental leave (odds ratio of $1.77, \mathrm{p}<0.05$ ). These results confirm hypothesis 1 , which stated that top managers would be more favorable toward flextime and telecommuting than leave arrangements and part-time hours. In line with hypothesis 2, top managers are more likely to support work-life arrangements when no financial investments are required, as opposed to when additional costs are involved (odds ratio of $1.60, \mathrm{p}<0.01$ ). Additionally, top managers take the expected increase in commitment into account in their evaluation of the vignettes: they are more likely to support work-life arrangements when an increase in commitment is to be expected than when the returns in terms of commitment are unclear (odds ratio of 1.59, $p<0.01$ ), confirming hypothesis 3. Contradicting the expectations in hypothesis 4, the model shows that in general, top managers tend to support work-life arrangements more when they are aimed at all employees than when they are aimed only at high-performing employees (odds ratio of $0.41, \mathrm{p}<0.01$ ). Hence, the model does not support the claim that top managers support custom work-life arrangements to attract and retain the best employees over general work-life arrangements for all employees. On the contrary: they favor the latter.

The hypotheses that are mainly based on neo-institutional theory are not supported. Hypothesis 5 stating that top managers are more likely to support work-life arrangements when their competitors do so is not confirmed, as this vignette factor is not significant (odds ratio of 1.12, $\mathrm{p}>0.1$ ). Contradicting hypothesis 6 , there seems to be no large significant difference between countries in whether top managers support work-life arrangements or not. There are no significant differences between the Netherlands (reference category) and the U.K. (odds ratio of 1.46, p > 0.1), Finland (odds ratio of 1.82, $\mathrm{P}>0.1$ ) and Portugal (odds ratio of 2.18, $\mathrm{p}=0.1$ ). The exception is Slovenia: top managers in this country are the most supportive of the work-life arrangements proposed in the vignettes (odds ratio of 9.79, $\mathrm{p}<0.01$ ).

Model 1 also shows that the expectation formulated based upon the managerial interpretation approach is not confirmed. Hypothesis 7-in which the expectations are formulated that female top managers (odds ratio of $0.84, \mathrm{p}>0.1$ ), those with children (odds ratio of 0.77, $\mathrm{p}>0.1$ ) and top managers who have personal experience with the use of work-life arrangements (odds ratio of $1.34, \mathrm{p}>0.1$ ) and/or work-life conflicts (odds ratio of $0.79, \mathrm{p}>0.1$ ) are more likely to support work-life arrangements-is not supported by the data.

Finally, the control variables in model 1 show no significant differences in the responses of top managers of organizations in the public sector, larger organizations and better financial conditions. Furthermore, top managers in different industries and with varying educational backgrounds did not rate the vignettes significantly different, nor did top managers who are living as married rate them differently from those who are single. The number of years that top managers had held their positions also did not affect how they judged the vignettes, nor did the age of the top managers make a difference.

Model 2 includes the interactions between vignette factors and the sector of the organization. The model shows that the expectations as formulated in hypothesis 8 are not supported: the costs associated with work-life arrangements are as important to top managers in public-sector organizations and NGOs as they are to top managers in private-sector organizations (odds ratio of $1.78, \mathrm{p}>0.1$ ). Furthermore, the model shows that top managers of both private and public-sector organizations and NGOs prefer work-life arrangements available to all employees as opposed to only high-performing employees. Nevertheless, in line with hypothesis 9, this preference is much stronger among top managers at public-sector organizations and NGOs (odds ratio of $0.08, \mathrm{p}<0.01$ ).

Model 3 includes the interactions between the types of work-life arrangements and countries. The model shows that hypothesis 10 is partly supported. Top managers in Slovenia (odds ratio of 4.76, $\mathrm{p}<0.05$ ) and Finland (odds ratio of 4.99, $\mathrm{p}<0.05$ ) are more supportive of flextime/telecommuting as opposed to part-time working hours (reference category) than those in the Netherlands (reference category) and the UK (odds ration 1.50, $p>0.05$ ). But this is also the case for top managers in Portugal (odds ratio of 5.88, $\mathrm{p}<0.01$ ). In addition, top managers in Finland (odds ratio of 3.95, $\mathrm{p}<0.05$ ) and Slovenia (odds ratio of 3.77, $\mathrm{p}<0.05$ ) are not less supportive of leave policies going beyond the statutory minimum as opposed to part-time working hours than those in the Netherlands (reference category). As expected, the UK shows no significant difference with the Netherlands (odds ratio of 2.46, $\mathrm{p}>0.05$ ).

\subsection{Sensitivity analyses}

To check the robustness of the results, several sensitivity checks were performed. First, we calculated some fixed effect models, as these represent a stricter test of whether top managers are actually responding to the factors included in the 
Table 3

Logistic multilevel regression models for top managers' support for work-life arrangements.

\begin{tabular}{|c|c|c|c|c|}
\hline Variables & Categories & $\begin{array}{l}\text { Model } 1 \\
\mathrm{OR}^{\mathrm{a}}\left(\mathrm{SE}^{\mathrm{b}}\right)\end{array}$ & $\begin{array}{l}\text { Model } 2 \\
\text { OR (SE) }\end{array}$ & $\begin{array}{l}\text { Model } 3 \\
\text { OR (SE) }\end{array}$ \\
\hline Constant & & $0.44(0.36)$ & $0.45(0.42)$ & $1.02(0.90)$ \\
\hline Vignette factors (level 1) & Factor levels & & & \\
\hline \multirow[t]{6}{*}{ Type of work-life arrangement } & Part time work & $\operatorname{Ref}^{\mathrm{C}}$ & ref & ref \\
\hline & Paid parental leave & $1.77(0.43)^{*}$ & $1.94(0.53)^{*}$ & - \\
\hline & Paid parental leave for fathers & $2.4(0.60)^{* *}$ & $2.81(0.75)^{* *}$ & - \\
\hline & Short term care leave & $3.43(0.87)^{* *}$ & $3.74(1.09)^{* *}$ & - \\
\hline & Telecommuting & $3.57(0.92)^{* *}$ & $4.15(1.27)^{* *}$ & - \\
\hline & Flextime & $6.28(1.72)^{* *}$ & $9.33(0.34)^{* *}$ & - \\
\hline \multirow[t]{3}{*}{ Type of work-life arrangement categories } & Part time work & ref & ref & ref \\
\hline & Telecommuting and flextime & - & - & $1.71(0.71)$ \\
\hline & Leave policies & - & - & $0.89(0.34)$ \\
\hline \multirow[t]{2}{*}{ Costs } & Investment needed & ref & ref & ref \\
\hline & No investment needed & $1.60(0.24)^{* *}$ & $1.52(0.30)^{*}$ & $1.60(0.24)^{* *}$ \\
\hline \multirow[t]{2}{*}{ Commitment } & No increase expected & ref & ref & ref \\
\hline & Increases & $1.59(0.24)^{* *}$ & $1.71(0.32)^{* *}$ & $1.65(0.26)^{* *}$ \\
\hline \multirow[t]{2}{*}{ Employee target group } & All employees & ref & ref & ref \\
\hline & Well performing employees & $0.41(0.06)^{* *}$ & $1.02(0.28)$ & $0.43(0.06)^{* *}$ \\
\hline \multirow[t]{2}{*}{ Other organizations } & Do not provide it & ref & ref & ref \\
\hline & Also provide it & $1.12(0.17)$ & $1.15(0.19)$ & $1.13(0.17)$ \\
\hline Other variables (level 2) & Categories & & & \\
\hline \multirow{5}{*}{ Country } & Netherlands & ref & ref & ref \\
\hline & Finland & $1.82(0.59)$ & $1.70(0.63)$ & $0.55(0.32)$ \\
\hline & Portugal & $2.18(0.66)$ & $1.58(0.55)$ & $0.53(0.28)$ \\
\hline & Slovenia & $9.79(3.69)^{* *}$ & $8.28(3.58)^{* *}$ & $3.16(1.84)^{*}$ \\
\hline & $U K$ & $1.46(0.49)$ & $1.82(0.70)$ & $0.80(0.47)$ \\
\hline \multirow[t]{2}{*}{ Sector } & Private & ref & ref & ref \\
\hline & Public/NGO & $1.49(0.44)$ & $3.58(1.49)^{* *}$ & $1.51(0.45)$ \\
\hline \multirow[t]{2}{*}{ Sex } & Male & ref & ref & ref \\
\hline & Female & $0.84(0.20)$ & $0.82(0.22)$ & $0.83(0.20)$ \\
\hline \multirow[t]{2}{*}{ Personal use of work-life arrangements } & No & ref & ref & ref \\
\hline & Yes & $1.34(0.30)$ & $1.24(0.31)$ & $1.33(0.30)$ \\
\hline \multirow{2}{*}{ Personal experience work-life conflict } & No & ref & ref & ref \\
\hline & Yes & $0.79(0.17)$ & $0.75(0.19)$ & $0.78(0.18)$ \\
\hline \multirow[t]{2}{*}{ Children } & No & ref & ref & ref \\
\hline & Yes & $0.77(0.20)$ & $0.91(0.26)$ & $0.78(0.21)$ \\
\hline Interactions & & & & \\
\hline Sector $*$ costs & & - & $1.78(0.67)$ & - \\
\hline Sector * employee target group & & - & $0.08(0.04)^{* *}$ & - \\
\hline Telecommuting/flextime ${ }^{*}$ UK & & - & - & $1.50(1.00)$ \\
\hline Telecommuting/flextime ${ }^{*}$ Slovenia & & - & - & $4.76(3.43)^{*}$ \\
\hline Telecommuting/flextime ${ }^{*}$ Finland & & - & - & $4.99(3.42)^{*}$ \\
\hline Telecommuting/flextime * Portugal & & - & - & $5.88(3.64)^{* *}$ \\
\hline Leave arrangements * UK & & - & - & $2.46(1.51)$ \\
\hline Leave arrangements * Slovenia & & - & - & $3.77(2.37)^{*}$ \\
\hline Leave arrangements * Finland & & - & - & $3.95(2.46)^{*}$ \\
\hline Leave arrangements * Portugal & & - & - & $5.39(3.01)^{* *}$ \\
\hline Control variables & & & & \\
\hline Age & & $1.00(0.01)$ & $0.99(0.02)$ & $1.00(0.01)$ \\
\hline Size & Small $(10-100)$ & ref & ref & ref \\
\hline & Middle (101-1000) & $0.98(0.26)$ & $1.13(0.33)$ & $0.98(0.26)$ \\
\hline & Large $(>1001)$ & $1.13(0.31)$ & $1.35(0.42)$ & $1.13(1.04)$ \\
\hline Educational direction & Business \& beta & ref & ref & ref \\
\hline & Alpha \& Gamma & $0.46(0.12)^{* *}$ & $0.43(0.12)^{* *}$ & $0.46(0.12)^{* *}$ \\
\hline & Below university level & $1.04(0.40)$ & $1.58(0.70)$ & $1.04(0.38)$ \\
\hline Industry & Private services & ref & ref & ref \\
\hline & Public services & $0.55(0.20)$ & $0.41(0.17)^{*}$ & $0.54(0.20)$ \\
\hline & Production \& retail & $0.56(0.17)$ & $0.43(0.14)^{*}$ & $0.55(0.17)$ \\
\hline & Knowledge work & $0.95(0.28)$ & $0.88(0.29)$ & $0.96(0.28)$ \\
\hline Married & No & ref & Ref & ref \\
\hline & Yes & $0.85(0.35)$ & $0.77(0.37)$ & $0.86(0.36)$ \\
\hline Financial situation of the organization & & $1.06(0.13)$ & $1.12(0.15)$ & $1.05(0.13)$ \\
\hline Tenure & & $1.04(0.02)$ & $1.03(0.02)$ & $1.04(0.02)$ \\
\hline Model specifications & & & & \\
\hline Random intercept & & $0.90(0.13)$ & $0.75(0.32)$ & $0.91(0.13)$ \\
\hline Random slope & Costs & - & $0.00(3372)$ & - \\
\hline & Employee target group & - & $1.88(0.32)$ & - \\
\hline & Telecommuting/flextime & & & $0.00(766)$ \\
\hline & Leave arrangements & & & $0.00(38934)$ \\
\hline & & & $(c$ & on next page) \\
\hline
\end{tabular}


Table 3 (continued)

\begin{tabular}{|c|c|c|c|c|}
\hline Variables & Categories & $\begin{array}{l}\text { Model } 1 \\
\mathrm{OR}^{\mathrm{a}}\left(\mathrm{SE}^{\mathrm{b}}\right)\end{array}$ & $\begin{array}{l}\text { Model } 2 \\
\text { OR (SE) }\end{array}$ & $\begin{array}{l}\text { Model } 3 \\
\text { OR (SE) }\end{array}$ \\
\hline $\mathrm{N}$ (vignettes) & & 1212 & 1212 & 1212 \\
\hline $\mathrm{N}$ (top managers) & & 202 & 202 & 202 \\
\hline
\end{tabular}

Note $1:{ }^{* *} \mathrm{p}<0.01{ }^{*} \mathrm{p}<0.05$ (two-tailed tests).

Note 2: Multiple imputation was used to account for missing data.

a Odds Ratios.

b Standard Error.

c Reference category.

vignettes. No differences were found. Second, multilevel regression models have also been calculated to check the response to vignette characteristics using another dependent variable in which top managers were asked to rate the idea proposed in the vignette on a scale of 1 (very negative) to 10 (very positive). The results were similar and are presented in appendix 1 . Third, we controlled for the vignette set assigned to each top manager and the percentage of female employees. This made no difference. Fourth, we also dealt with missing values trough means of list-wise deletion. The response to vignette characteristics was the same. Fifth, we added size using the log and square root (separate models) rather than as a categorical variable. Size was not significant in either of the models.

\section{Conclusion and discussion}

Since the rise of dual-earner families, scholars have been interested in whether and why organizations provide worklife arrangements to employees to support them in combining responsibilities at work and in their private lives. This literature has so far generally side-stepped the actors who decide about the adoption and implementation of these arrangements within organizations and treated organizations as if they could somehow make the decisions themselves. However, in fact, it is top managers within the organizations who make these decisions (Elbanna, 2006; Finkelstein and Hambrick, 1996; Ginsberg, 1988). This study contributes to the literature regarding the provision of work-life arrangements by introducing top managers as the decision-making actors regarding the provision of work-life arrangements. Through means of employing a factorial survey design in five European countries, the conditions under which top managers decide whether to support work-life arrangements are explored. Based upon the conditions found to be relevant for top managers' support for work-life arrangements, it can be concluded that, overall, they mainly support work-life arrangements because they see them as a business case. In line with business case argumentation, top managers' were likely to support work-life arrangements when there are few financial consequences for the organization and when the arrangements are likely to contribute to employee commitment. However, the preference of top managers for work-life arrangements that target all employees equally over custom work-life arrangements for high-performing employees suggests that not only pure business case arguments play a role. After all, providing custom work-life arrangements only to well-performing employees would most likely be cheaper and easier in terms of organizing the work than providing them to everyone within the organization and would, therefore, be more in line with business case arguments (Caligiuri and Givelekian, 2008). A possible explanation for the preference of top managers to provide them to all employees is that they are also sensitive to societal norms. Providing them to a select group might jeopardize social legitimacy, especially in a context where equal treatment of employees is valued, which is more the case in European countries than in the United States. This would be in line with neo-institutional theory. Alternatively, it could be the case that business case arguments still underlie the preference. In that case, top managers would see the provision of work-life arrangements for all employees as most beneficial for the company because it attracts and retains larger groups of employees to the company, which enables hand-picking employees. More research, preferably including substantial interviews, might clarify this issue. Notwithstanding what underlies it, the preference of top managers for work-life arrangements aimed at all employees implies that in the European context of this study, work-life arrangements are seen as general terms of employment rather than personal remunerations. Encouragement to provide work-life arrangements would, therefore, most likely be heard by organizations if they emphasize what the organization could gain by implementing it in the overarching organization's approach to work.

Although a common idea is that personal experiences and characteristics matter for managers' support for work-life arrangements (Hambrick and Mason, 1984; Hopkins, 2005; Klein et al., 2000), no evidence was found for this being the case for top managers. Male and female top managers are equally supportive of work-life arrangements; whether they have children does not make a difference, and it does not matter for top managers' support whether they have used or are currently using work-life arrangements or whether they have experienced work-life balance issues. Their decisions about the general organizational approach toward work-life arrangements seem to be based more on business considerations and social norms rather than these personal experiences. It could be that they experience decisions regarding work-life arrangements primarily in their role as top managers who are responsible for the prosperity of the organization, which results in their linking it to the needs of the organization and keeping their personal perspective and experiences out of their deliberation. This might be especially the case because the idea of work-life arrangements is already quite common in society, and top managers deciding to support them are no longer pioneers. Therefore, their personal vision might be 
less relevant for the decision. Another explanation is that more nuanced personal differences between top managers play a role.

Based upon the results, it can be concluded that how heavily top managers weigh certain conditions of work-life arrangements depends on the organizational and national contexts. Regarding the organizational context, mainly the division between top managers of public- and private-sector organizations was found to matter. Top managers of public-sector organizations were more concerned with providing work-life arrangements to all employees equally; this can be interpreted as a reflection of the greater reliance on social legitimacy of public-sector organizations. This also supports the claim that it is normative pressure that leads top managers preferring work-life arrangements aimed at all employees rather than the business case argument of attracting larger groups of employees to the organization. After all, this argument would be just as valid in the context of private sector organizations.

That the conditions on which top managers base their support for work-life arrangements also depend on the national context is shown by the extent to which top managers in different countries support different types of work-life arrangements. When opposed to part-time work hours, top managers in Finland, Portugal and Slovenia are more supportive of telecommuting/flextime as well as leave arrangements than top managers in the Netherlands and the UK. This is partly, but not only, the result of a stronger disregard of part-time working hours in Finland and Portugal than in the other countries. Thus, the results of this study only support the claim that organizations in countries where the government provides many state work-life policies tend to provide more flextime and telecommuting as a result of normative pressure. However, the claim that they are at the same time less supportive of extending leave arrangements because this is seen as a government responsibility is not supported (Den Dulk et al., 2010). That top managers not only support flextime/telecommuting more in Finland, Slovenia and Portugal, but that they also have a stronger disregard for part-time working hours cannot be understood solely from differences in normative pressure. After all, in the Portuguese society work-life arrangements are not that common yet and therefore normative pressure can be expected to play a minor role. A likely explanation is that also the national working hour culture plays a role: in Portugal, Slovenia and Finland full-time hours are the norm whereas this is less so in the UK and the Netherlands. Nevertheless, these conclusions should be drawn with care. Because of the relatively small number of countries included in this study, no direct test was possible. Other national differences, such as different cultural expectations, could also underlie the difference. What we can conclude with certainty, however, is that it varies between countries to which extent different types of work-life arrangements are supported by top managers.

Based upon this study, it is clear that of the different types of work-life arrangements, telecommuting and flextime are generally most supported by top managers. One explanation is that those arrangements have fewest consequences for employee output because they do not alter an employee's number of work hours (Powell and Mainiero, 1999). However, this support should also be seen in the light of the developments of the last decade. The rapid technological developments have made it increasingly easy to adopt these arrangements within organizations, and employers recognized that allowing employees to telecommute could reduce office space. Nevertheless, managers and supervisors down the hierarchy of the organization might not share this opinion, as research shows that they see these arrangements as disturbing for the organization of work (Den Dulk and De Ruijter, 2008). As flexibility in time and space is seen as the future in that this is the preferred way employees should combine work and personal responsibilities according to top managers, top managers should ensure that this perspective is supported by all supervisors throughout the organization. Otherwise, employees might be caught between formal arrangements and unwilling supervisors.

This study has a number of limitations. First, it includes a relatively small number of top managers per country. Future studies could include more top managers to ensure the robustness of the results. Second, because only five countries were included, it was only possible to explore cross-country differences. Future research could extend this study to a larger number of countries to test the origins of these differences. Third, the vignette characteristics included were a selection of possible conditions on which top managers base their decisions. Future research could broaden the scope of conditions taken into account. Fourth, the way we operationalized mimetic pressure might have led to an underestimation of its effect on top managers' decision-making: different top managers might have envisioned a varying number of other organizations in their field considering adopting work-life arrangements. Therefore, the amount of mimetic pressure they perceived might have varied. More research can focus on how important mimetic pressure potentially is to top managers' decisionmaking in various contexts with more and less mimetic pressure. Fifth, no multi-nationals were included. This would be interesting to include in future research, as policies and work-life arrangements are set at both the supra-national and national levels. These levels could be fruitful settings to further explore the role of the national context relative to that of the organization.

\section{Acknowledgements}

This work was supported by The Netherlands Organisation for Scientific Research (grant number 461-04-780). 
Appendix 1. Multilevel regression models with 'degree of top managers' support' for the vignette as dependent variable.

\begin{tabular}{|c|c|c|c|c|}
\hline Variables & Categories & $\begin{array}{l}\text { Model }{ }^{C} \\
B\left(\mathrm{SE}^{\mathrm{C}}\right)\end{array}$ & $\begin{array}{l}\text { Model } 2^{\mathrm{D}} \\
\mathrm{B}(\mathrm{SE})\end{array}$ & $\begin{array}{l}\text { Model } 3^{\mathrm{D}} \\
\mathrm{B}(\mathrm{SE})\end{array}$ \\
\hline Constant & & $4.12(0.89)$ & $4.34(0.87)$ & $5.08(0.92)$ \\
\hline Vignette factors (level 1) & Factor levels & & & \\
\hline \multirow[t]{6}{*}{ Type of work-life arrangement } & Part time work & $\operatorname{ref}^{\mathrm{B}}$ & ref & ref \\
\hline & Paid parental leave & $0.45(0.23)^{*}$ & $0.48(0.22)^{*}$ & - \\
\hline & Paid parental leave for fathers & $1.02(0.22)^{* *}$ & $1.02(0.21)$ & - \\
\hline & Short term care leave & $1.24(0.22)^{* *}$ & $1.18(0.21)^{* *}$ & - \\
\hline & Telecommuting & $1.50(0.22)^{* *}$ & $1.48(0.22)^{* *}$ & - \\
\hline & Flextime & $2.03(0.22)^{* *}$ & $2.07(0.21)^{* *}$ & - \\
\hline \multirow{3}{*}{ Type of work-life arrangement categories } & Part time work & ref & ref & ref \\
\hline & Telecommuting and flextime & - & - & $0.72(0.39)$ \\
\hline & Leave policies & - & - & $-0.28(0.38)$ \\
\hline \multirow{2}{*}{ Costs } & Investment needed & ref & ref & ref \\
\hline & No investment needed & $0.48(0.13)^{* *}$ & $0.45(0.14)^{* *}$ & $0.48(0.13)^{* *}$ \\
\hline \multirow[t]{2}{*}{ Commitment } & No increase expected & ref & ref & ref \\
\hline & Increases & $0.55(0.13)^{* *}$ & $0.52(0.14)^{* *}$ & $0.58(0.14)^{* *}$ \\
\hline \multirow[t]{2}{*}{ Employee target group } & All employees & ref & ref & ref \\
\hline & Well performing employees & $-0.78(0.13)^{* *}$ & $-0.30(0.19)$ & $-0.74(0.13)^{* *}$ \\
\hline \multirow{2}{*}{ Other organizations } & Do not provide it & ref & ref & ref \\
\hline & Also provide it & $0.10(0.13)$ & $0.10(0.12)$ & $0.11(0.13)$ \\
\hline Other variables (level 2) & Categories & & & \\
\hline \multirow[t]{5}{*}{ Country } & Netherlands & ref & ref & ref \\
\hline & Finland & $0.66(0.37)$ & $0.62(0.36)$ & $-0.69(0.58)$ \\
\hline & Portugal & $0.82(0.34)^{*}$ & $0.55(0.33)$ & $-0.83(0.53)$ \\
\hline & Slovenia & $2.11(0.39)^{* *}$ & $1.73(0.38)^{* *}$ & $1.20(0.57)^{*}$ \\
\hline & UK & $0.34(0.39)$ & $0.62(0.38)$ & $-0.55(0.59)$ \\
\hline \multirow[t]{2}{*}{ Sector } & Private & ref & ref & ref \\
\hline & Public/NGO & $0.34(0.33)$ & $0.95(0.37)^{* *}$ & $0.31(0.33)$ \\
\hline \multirow[t]{2}{*}{ Sex } & Male & ref & ref & ref \\
\hline & Female & $-0.31(0.27)$ & $-0.20(0.26)$ & $-0.29(0.27)$ \\
\hline \multirow[t]{2}{*}{ Personal use of work-life arrangements } & No & ref & ref & ref \\
\hline & Yes & $0.36(0.25)$ & $0.30(0.24)$ & $0.37(0.25)$ \\
\hline \multirow{2}{*}{ Personal experience work-life conflict } & No & ref & ref & ref \\
\hline & Yes & $0.00(0.24)$ & $-0.02(0.24)$ & $-0.01(0.24)$ \\
\hline \multirow[t]{2}{*}{ Children } & No & ref & ref & ref \\
\hline & Yes & $-0.23(0.30)$ & $-0.07(0.28)$ & $-0.19(0.29)$ \\
\hline \multicolumn{5}{|l|}{ Interactions } \\
\hline \multicolumn{2}{|l|}{ Sector * costs } & - & $0.15(0.27)$ & - \\
\hline Sector * employee target group & & - & $-10.63(0.35)^{* *}$ & - \\
\hline Telecommuting/flextime * UK & & - & - & $0.88(0.63)$ \\
\hline Telecommuting/flextime * Slovenia & & - & - & $0.84(0.58)$ \\
\hline Telecommuting/flextime * Finland & & - & - & $1.72(0.62)^{* * *}$ \\
\hline Telecommuting/flextime * Portugal & & - & - & $1.88(0.55)^{* *}$ \\
\hline Leave arrangements * UK & & - & - & $1.15(0.61)$ \\
\hline Leave arrangements * Slovenia & & - & - & $1.22(0.56)^{*}$ \\
\hline Leave arrangements * Finland & & - & - & $1.55(0.60)^{*}$ \\
\hline Leave arrangements * Portugal & & - & - & $2.07(0.54)^{* *}$ \\
\hline Control variables & & & & \\
\hline Age & & $0.01(0.02)$ & $-0.00(0.02)$ & $0.01(0.02)$ \\
\hline Size & Small $(10-100)$ & ref & ref & ref \\
\hline & Middle (101-1000) & $-0.25(0.30)$ & $-0.18(0.29)$ & $-0.26(0.30)$ \\
\hline & Large (>1001) & $0.12(0.31)$ & $0.26(0.30)$ & $0.10(0.32)$ \\
\hline Educational direction & Business \& beta & Ref & Ref & Ref \\
\hline & Alpha \& Gamma & $-0.52(0.30)$ & $-0.51(0.28)^{* *}$ & $-0.50(0.29)^{* *}$ \\
\hline & Below university level & $-0.20(0.42)$ & $0.03(0.40)$ & $-0.22(0.42)$ \\
\hline Industry & Private services & ref & ref & ref \\
\hline & Public services & $-0.06(0.41)$ & $-0.24(0.40)$ & $-0.04(0.41)$ \\
\hline & Production \& retail & $-0.62(0.33)$ & $-0.77(0.32)^{*}$ & $-0.65(0.33)^{*}$ \\
\hline & Knowledge work & $-0.05(0.32)$ & $-0.06(0.32)$ & $0.00(0.33)$ \\
\hline Married & No & ref & Ref & ref \\
\hline & Yes & $-0.01(0.44)$ & $-0.04(0.43)$ & $-0.00(0.44)$ \\
\hline Financial situation of the organization & & $0.11(0.13)$ & $0.17(0.13)$ & $0.09(0.13)$ \\
\hline Tenure & & $0.02(0.02)$ & $0.01(0.02)$ & $0.02(0.02)$ \\
\hline Model specifications & & & & \\
\hline Random intercept & & $1.24(0.10)$ & $1.09(0.10)$ & $1.20(0.10)$ \\
\hline
\end{tabular}




\begin{tabular}{|c|c|c|c|c|}
\hline Variables & Categories & $\begin{array}{l}\text { Model }{ }^{\mathrm{C}}{ }^{\mathrm{C}} \\
\mathrm{B}(\mathrm{SE})^{-1}\end{array}$ & $\begin{array}{l}\text { Model } 2^{\mathrm{D}} \\
\mathrm{B}(\mathrm{SE})\end{array}$ & $\begin{array}{l}\text { Model } 3^{D} \\
B(S E)\end{array}$ \\
\hline Random slope & $\begin{array}{l}\text { Costs } \\
\text { Employee target group } \\
\text { Telecommuting/flextime } \\
\text { Leave arrangements }\end{array}$ & - & $\begin{array}{l}0.00(0.00) \\
1.48(0.16)\end{array}$ & $\begin{array}{l}- \\
- \\
0.49(0.39) \\
0.79(0.21)\end{array}$ \\
\hline $\begin{array}{l}\mathrm{N} \text { (vignettes) } \\
\mathrm{N} \text { (top managers) }\end{array}$ & & $\begin{array}{l}1212 \\
202\end{array}$ & $\begin{array}{l}1212 \\
202\end{array}$ & $\begin{array}{l}1212 \\
202\end{array}$ \\
\hline
\end{tabular}

Notes: ${ }^{* *} \mathrm{p}<0.01{ }^{*} \mathrm{p}<0.05$ (two-tailed tests).

Note 2: Multiple imputation was used to account for missing data.

A: Standard Error.

B: Reference category.

C: Random intercept model.

D: Random intercept, random slope models.

\section{References}

Aberbach, Joel D., Rockman, Bert A., 2002. Conducting and coding elite interviews. Political Sci. Polit. 35 (4), 673-676.

Allen, Tammy D., 2001. Family-supportive work environments: the role of organizational perceptions. J. Vocat. Behav. 58, 414-435.

Atzmüller, Christiane, Steiner, Peter M., 2010. Experimental vignette studies in survey research. Methodology 6 (3), 128-138.

Bardoel, E. Anne, 2003. The provision of formal and informal work-family practices: the relative importance of institutional and resource dependent explanations versus managerial explanations. Women Manag. Rev. 18 (1/2), 7-19.

Barney, Jay, 1991. Firm resources and sustained competitive advantage. J. Manag. 17 (1), 99-120.

Caligiuri, Paula, Givelekian, Nicole, 2008. Strategic human resources and work-life balance. In: Poelmans, S.A.Y., Caligiuri, P., 19-38 (Eds.), Harmonizing Work, Family and Personal Life. Cambridge University Press, Cambridge.

Cook, Alison, 2004. Corporate decision-making processes: how organizations decide to adopt work/life initiatives. In: Kossek, E.E., Pitt-Catsouphes, M. (Eds. ). Work and Family Encyclopedia. Sloan work and family research network, Chestnut Hill, MA.

Davis, Amy E., Kalleberg, Arne L., 2006. Family-Friendly Organizations? Work and family programs in the 1990s. Work Occup. 332, $191-223$.

Den Dulk, Laura, 2001. Work-family Arrangements in Organizations: a Cross-national Study in the Netherlands, Italy, the United Kingdom and Sweden. Rozenberg Publishers, Amsterdam.

Den Dulk, Laura, Groeneveld, Sandra, 2012. Work-life balance support in the public sector in Europe. Rev. Public Personnel Adm. 33 (4), $384-405$.

Den Dulk, Laura, Peters, Pascalle, Poutsma, Erik, Ligthart, Paul E.M., 2010. The extended business case for childcare and leave arrangements in western and eastern Europe. Baltic J. Manag. 5 (2), 156-184.

Den Dulk, Laura, Peters, Pascalle, Poutsma, Erik, 2012. Variations in adoption of workplace work-family arrangements in Europe: the influence of welfarestate regime and organizational characteristics. Int. J. Hum. Resour. Manag. 23 (13), 2785-2808.

Den Dulk, Laura, Groeneveld, Sandra, Ollier-Malaterre, Ariane, Valcour, Monique, 2013. National context in work-life research: a multi-level cross-national analysis of the adoption of workplace work-life arrangements in Europe. Eur. Manag. J. 31, 478-494.

Den Dulk, Laura, De Ruijter, Judith, 2008. Managing work-life policies: disruption versus dependency arguments. Explaining managerial attitudes towards employee utilization of work-life policies. Int. J. Hum. Resour. Manag. 19 (7), 1222-1236.

Dex, S., Scheibl, F., 2001. Flexible and family-friendly working arrangements in UK-based SMEs: business cases. Br. J. Industrial Relat. $39,411-431$.

DiMaggio, Paul J., Powell, Walter W., 1983. The iron cage revisited: institutional isomorphism and collective rationality in organizational fields. Am. Sociol. Rev. 48, 147-160.

Eurofound, 2010. European Company Survey 2009. Office for Official Publications of the European Communities, Luxembourg.

Elbanna, Said, 2006. Strategic decision-making: process perspectives. Int. J. Manag. Rev. 8 (1), 1-20.

Esping-Andersen, Gøsta, 1999. Social Foundations of Postindustrial Economies. Oxford University Press, New York, NY.

Finkelstein, Sydney, Hambrick, Donald C., 1996. Strategic Leadership: Top Executives and Their Effects on Organizations. West Publishing Company, St. Paul.

Ginsberg, Ari, 1988. Measuring and modeling changes in strategy: theoretical foundations and empirical directions. Strategic Manag. J. 9 (6), $559-575$.

Glass, Jennifer, Fujimoto, Tetsushi, 1995. Employer characteristics and the provision of family responsive policies. Work Occup. $22,380-411$.

Goldstein, Kenneth, 2002. Getting in the door: sampling and completing elite interviews. Political Sci. Polit. 35 (4), 669-672.

Goodstein, Jerry D., 1994. Institutional pressures and strategic responsiveness: employer involvement in work-family issues. Acad. Manag. J. 37 (2), $350-382$.

Haar, Jarrod M., Spell, Chester S., 2004. Programme knowledge and value of work-family practices and organizational commitment. Int. J. Hum. Resour. Manag. 15 (6), 1040-1055.

Hambrick, Donald C., Mason, Phyllis A., 1984. Upper echelons: the organization as a reflection of its top managers. Acad. Manag. Rev. 9 (2), 193-206.

Hopkins, Karen, 2005. Supervisor support and work-life integration: a social identity perspective. In: Kossek, E.E., Lambert, S.J. (Eds.), Work and Life Integration: Organizational, Cultural and Individual Perspective. Lawrence Erlbaum Associated Publishers, London, pp. 423-444.

Hornung, Severin, Rousseau, Denise M., Glaser, Jurgen, 2009. Why supervisors make idiosyncratic deals: antecedents and outcomes of I-deals from a managerial perspective. J. Manag. Psychol. 24 (8), 738-764.

Ingram, Paul, Simons, Tal, 1995. Institutional and resource dependence determinants of responsiveness to work-family issues. Acad. Manag. J. 38 (5), $1466-1482$.

Jones, David A., Willness, Chelsea R., Madey, Sarah, 2013. Why are job seekers attracted by corporate social Performance? Experimental and field tests of three signal-based mechanisms. Acad. Manag. J. 57 (2), 383-404.

Klein, Katherine J., Berman, Lori M., Dickson, Marcus W., 2000. May I work part-time? An exploration of predicted employer responses to employee requests for part-time work. J. Vocat. Behav. 57, 85-101.

Konrad, Alison M., Mangel, Robert, 2000. The impact of work-life programs on firm productivity. Strategic Manag. J. 21, 1225-1237.

Korabic, Karen, Lero, Donna, Ayman, Roya, 2003. A multi-level approach to cross-cultural work-family research: a micro- and macro-perspective. Int. J. Cross Cult. Manag. 3, 289-303.

Kossek, Ellen E., Dass, Parshotam, DeMarr, Beverly, 1994. The dominant logic of employer-sponsored work and family initiatives: human resource managers' institutional role. Hum. Relat. 47, 1121-1149.

Lambert, Susan T., 2000. Added benefits: the link between work-life benefits and organizational citizenship behavior. Acad. Manag. J. 43 (5), 801 -815.

Lewis, Suzan, 2003. Flexible work arrangements: implementation, outcomes and management. Int. Rev. industrial Organ. Psychol. 18, 1-28.

Lewis, Suzan, Haas, Linda, 2005. Work-life integration and social policy: a social justice theory and gender equity approach to work and family. In: Kossek, E. E., Lambert, S.J. (Eds.), Work and Life Integration: Organizational, Cultural and Individual Perspectives. Lawrence Erlbaum Associated Publishers, London, pp. 349-374. 
Lyness, Karen S., Kropf, Marcia B., 2005. The relationships of national gender equality and organizational support with work-family balance: a study of european managers. Hum. Relat. 58, 33-60.

Mescher, Samula, Benschop, Yvonne, Doorewaard, Hans, 2010. Representations of work-life balance support. Hum. Relat. 63 (21), 21-39.

Milliken, Frances J., Martins, Luis L., Morgan, Hal, 1998. Explaining organizational responsiveness to work-family issues: the role of human resource executives as issue interpreters. Acad. Manag. J. 41 (5), 580-592.

Morgan, Hal, Milliken, Frances J., 1992. Keys to action: understanding differences in organizations' responsiveness to work-and-Family issues. Hum. Resour. Manag. 31 (3), 227-248.

Muse, Lori, Harris, Stanley G., Giles, William F., Field, Hubert S., 2008. Work-life benefits and positive organizational behavior: is there a connection? J. Organ. Behav. 29, 171-192.

Niemistö, Charlotta, 2011. Work/family Reconciliation: Corporate Management, Family Policies and, Gender Equality in the Finnish Context. Hanken School of Economics, Helsinki.

Oliver, Christine, 1991. Strategic responses to institutional processes. Acad. Manag. Rev. 16, 145-179.

Ollier-Malaterre, Ariane, 2009. Organizational work-life initiatives: context matters. France compared to the UK and the us. Community, Work Fam. 12 (2), 159-178.

Ollier-Malaterre, Ariane, McNamara, Tay, Matz-Costa, Christina, Pitt-Catsouphes, Marcie, Valcour, Monique, 2013. Looking up to regulations, out at peers or down at the bottom line: how institutional logics affect the prevalence of age-related HR practices. Hum. Relat. 66 (10), $1373-1395$.

Osterman, Paul, 1995. Work/family programs and the employment relationship. Adm. Sci. Q. 40 (4), $681-700$.

Poelmans, Steven A.Y., Chinchilla, Nuria, Cardona, Pablo, 2003. The adoption of family-friendly HRM policies: competing for scarce resources in the labour market. Int. J. Manpow. 24, 128-147.

Poelmans, Steven A.Y., Sahibzada, Khatera, 2004. A multi-level model for studying the context and impact of work-family policies and culture in organizations. Hum. Resour. Manag. Rev. 14, 409-431.

Powell, Gary N., Mainiero, Lisa A., 1999. Managerial decision-making regarding alternative work arrangements. J. Occup. Organ. Psychol. 72, 41-56.

Rossi, Peter H., Anderson, Andy B., 1982. The factorial survey approach: an introduction. In: Rossi, P.H., Nock, S.L. (Eds.), Measuring Social Judgments: the Factorial Survey Approach. Sage, Beverly Hills CA, pp. 15-67.

Saraceno, Chiara, 2011. Childcare needs and childcare policies: a multidimensional issue. Curr. Sociol. 59 (1), 78 -96.

Stropnik, Nada, Sircelj, Milivoja, 2008. Slovenia: generous family policy without evidence of any fertility impact. Demogr. Res. $19,1019-1058$.

Turban, Daniel B., Greening, Daniel W., 1996. Corporate social performance and organizational attractiveness to prospective employees. Acad. Manag. J. 40 (3), 658-672.

United Nations Development Programme, 2011. Human Development Report 2011. Sustainability and Equity: a Better Future for All. Palgrave MacMillan, New York.

Wallander, Lisa, 2009. 25 Years of factorial surveys in sociology: a review. Soc. Sci. Res. 38, 505-520.

Wood, J. Stephen, Menezes, Lilian M., Lasaosa, Ana, 2003. Family-Friendly management in great britain: testing various perspectives. Ind. Relat. 42 (2), 221-250. 